\title{
Early- and advanced non-enzymatic glycation in diabetic vascular complications: the search for therapeutics
}

\author{
Casper G. Schalkwijk • Toshio Miyata
}

Received: 20 May 2010/ Accepted: 23 August 2010/Published online: 20 October 2010

(C) The Author(s) 2010. This article is published with open access at Springerlink.com

\begin{abstract}
Cardiovascular disease is a common complication of diabetes and the leading cause of death among people with diabetes. Because of the huge premature morbidity and mortality associated with diabetes, prevention of vascular complications is a key issue. Although the exact mechanism by which vascular damage occurs in diabetes in not fully understood, numerous studies support the hypothesis of a causal relationship of non-enzymatic glycation with vascular complications. In this review, data which point to an important role of Amadori-modified glycated proteins and advanced glycation endproducts in vascular disease are surveyed. Because of the potential role of early- and advanced non-enzymatic glycation in vascular complications, we also described recent developments of pharmacological inhibitors that inhibit the formation of these glycated products or the biological consequences of glycation and thereby retard the development of vascular complications in diabetes.
\end{abstract}

Keywords Diabetes - Non-enzymatic glycation - AGEs · Amadori-albumin · Vascular complications

C. G. Schalkwijk ( $₫)$

Department of Internal Medicine, University Hospital

Maastricht, P. Debyelaan 25, P.O. Box 5800,

6202 AZ Maastricht, The Netherlands

e-mail: C.Schalkwijk@INTMED.unimaas.nl

T. Miyata

United Centers for Advanced Research and Translational

Medicine (ART), Tohoku University Graduate School

of Medicine, 2-1 Seiryo-Machi, Aoba-ku, Sendai,

Miyagi 980-8575, Japan

e-mail: t-miyata@mail.tains.tohoku.ac.jp

\section{Introduction}

Cardiovascular disease is a common complication of diabetes and the leading cause of death among people with diabetes (Zimmet et al. 2001). Vascular complications in diabetes can be caused by micro- and macroangiopathy (Schalkwijk and Stehouwer 2005). Retinal and renal microangiopathy cause retinopathy and nephropathy, and microangiopathy of the vasa nervorum contributes to diabetic neuropathy. Macroangiopathy in diabetes consists mainly of an accelerated form of atherosclerosis and affects all clinically important sites, i.e. the coronary, the carotid and the peripheral arteries, thus increasing the risk of myocardial infarction, stroke and peripheral artery disease.

Dysfunction of the vascular endothelium is regarded not only as an important factor in the initiation of vascular complications but also in its progression and clinical sequelae (Cines et al. 1998). The results of large studies in type 1 and type 2 diabetes provide strong evidence that hyperglycaemia plays an important role in the pathogenesis of nephropathy, retinopathy, neuropathy and accelerated atherosclerosis (The Diabetes Control Complications Trial Research Group 1993; The Diabetes Control and Complications Trial/Epidemiology of Diabetes Interventions and Complications Research Group 2000; UK Prospective Diabetes Study (UKPDS) Group 1995, 1998). These studies also emphasised that hyperglycaemia is an independent risk factor for these vascular complications although the exact relationship between glucose control and macrovascular complications, especially in type 2 diabetes, is still a matter of debate (Skyler et al. 2009).

A growing body of evidence suggests that many hyperglycaemia-induced changes that explain the pathogenesis of vascular complications are mediated by early glycated proteins and/or advanced glycation endproducts (AGEs) 
(Goh and Cooper 2008; Genuth et al. 2005) (Fig. 1). Nonenzymatic glycation involves the condensation reaction of the carbonyl group of sugar aldehydes with the $\mathrm{N}$-terminus or free-amino groups of proteins via a nucleophilic addition, resulting first in the rapid formation of a Schiff base. Through acid-base catalysis, these labile adducts then undergo rearrangements to the more stable Amadoriproducts. Only a small part of these relatively stable Amadori-products undergo further irreversible chemical reactions leading to the formation of AGEs. An important distinction of AGEs, compared with their Amadori-products, is their irreversible nature. In the complex pathways leading to the formation of AGEs, it seems that oxidative stress plays an important role, and therefore, AGEs will also accumulate under conditions of oxidative stress and inflammation (Baynes and Thorpe 2000).

Because of the potential role of early- and advanced non-enzymatic glycation in vascular complications, the development of pharmacological inhibitors that inhibit the formation of these glycated products or the biological consequences of glycation and thereby retard the development of vascular complications in diabetes is of particular interest. In this review, data which point to an important role of Amadori-glycated proteins and AGEs in the development of vascular complications and recent developments in therapeutic interventions in the glycation pathway will be described.

\section{Amadori-glycated proteins and vascular complications}

The majority of the glycated proteins in plasma exist as Amadori-glycated proteins rather than as AGEs. On the basis of proteomic profiling, it was found that glucose attaches at many different sites in human serum albumin in vivo as evidenced by the 31 glycation sites (Zhang et al. 2008). In addition to albumin, other high-abundance plasma proteins were identified glycated including serotransferrin, alpha-1-antitrypsin, alpha-2-macroglobulin, apolipoprotein A-I and A-II, fibrinogen and alpha-1-acid glycoprotein as well as several moderately abundant glycated proteins (Jaleel et al. 2005; Dolhofer and Wieland 1980). Although several studies have demonstrated that the amount of Amadori-modified proteins is increased in diabetic patients, only limited data are available on the association of the plasma concentrations of Amadori-albumin with the presence and severity of diabetic complications. In a rodent model of type 2 diabetes, plasma Amadorialbumin concentrations were elevated twofold and declined after administration of a monoclonal anti-Amadori albumin, and this decrease was accompanied by a decrease of fibronectin (Cohen et al. 1994) indicating for the first time in vivo that Amadori-albumin contributes causally to diabetic vasculopathy. Indeed, infusion of Amadori-albumin in animal model induced a generalised diabetic vasculopathy (Cohen et al. 1996). In support, in type 1 diabetic

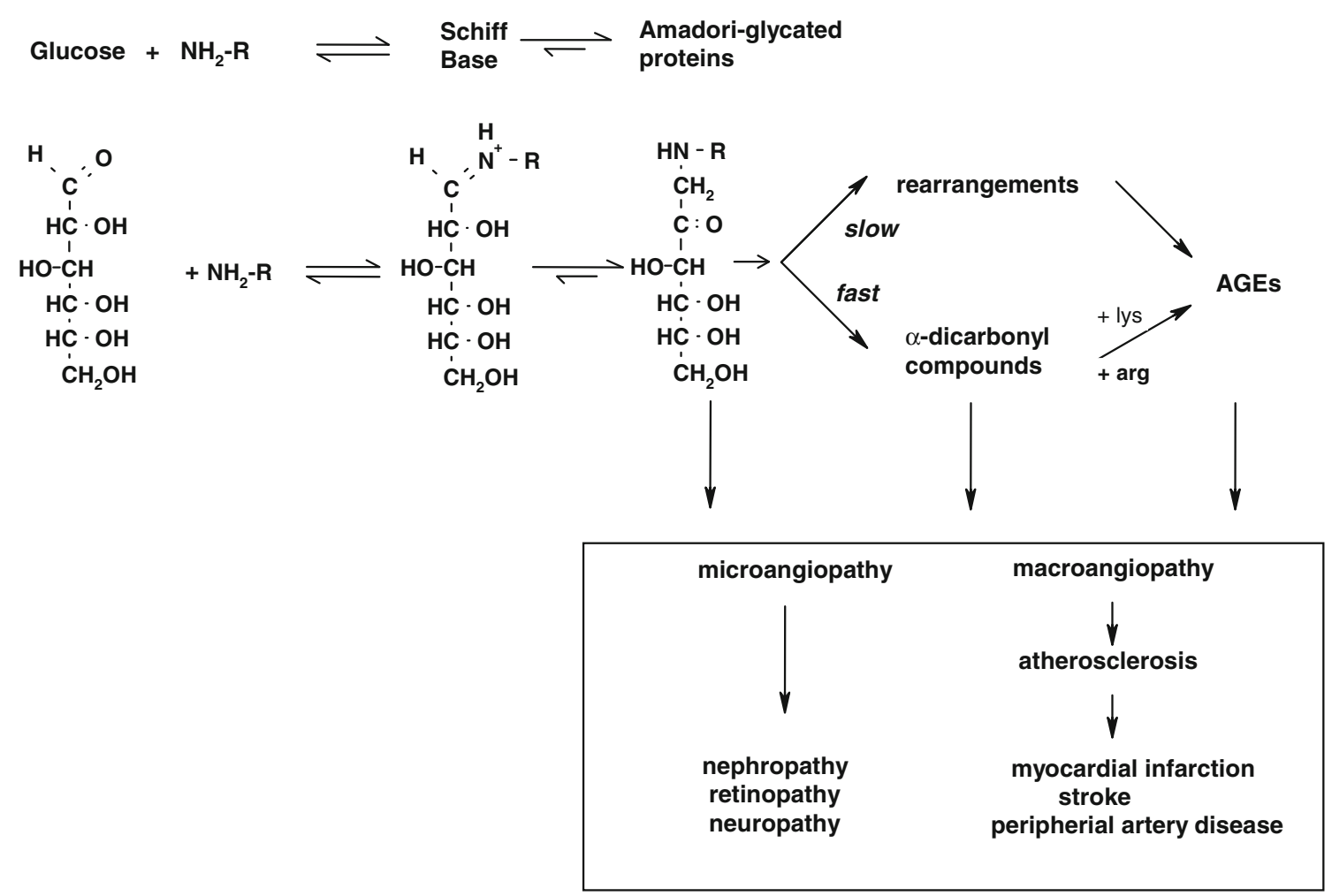

Fig. 1 Formation of Amadori-glycated proteins and advanced glycation endproducts (AGEs) and their putative role in vascular complications 
patients, Amadori-albumin correlated with the generally recognised plasma markers of endothelial or vascular dysfunction (Schalkwijk et al. 1999).

Amadori-albumin exhibits potential deleterious effects in various vascular cells types, which can be associated with vascular complications. Amadori-albumin has been shown to affect the biology of endothelial cells, such as TNF- $\alpha$ and E-selectin expression, and modulation of nitric oxide (NO) synthase activity (Amore et al. 1997; Higai et al. 2006). In human glomerular endothelial cells, Amadori-albumin caused an increase in type IV collagen, fibronectin and transforming growth factor- $\beta 1$ (TGF- $\beta 1$ ) expression, with an essential role of PKC signalling and TGF- $\beta 1$ activation in collagen production (Chen et al. 2003). Amadori-albumin also affects cell growth in glomerular mesangial cells and stimulated production of fibronectin, TGF- $\beta 1$, the TGF- $\beta$ type II receptor and type IV collagen with the protein kinase $\mathrm{C}$ (PKC)- $\beta 1$ isoform linked to the stimulation of type IV collagen production (Cohen et al. 2007; Ziyadeh 2004). In smooth muscle cells, Amadori-albumin increased the expression of monocyte chemoattractant protein-1 (MCP-1), increased the activation of PKC and induced cell proliferation (Hattori et al. 2002). Amadori-albumin-induced production of reactive oxygen species and activation of tyrosine kinase seemed to be involved in MCP-1 expression, while activation of mitogen-activated protein kinases (MAPK) by PKC activation seemed to be involved in cell proliferation.

Of note, the binding proteins for Amadori-glycated albumin reported so far in different cell types do not show any homology with various AGE receptors. In agreement, Amadori-albumin did not compete with AGE-albumin for binding to the receptor for AGE (RAGE) (Schmidt et al. 1999).

In accordance with the in vitro findings indicating a role of Amadori-glycated albumin in the pathology of vascular disease, the twofold increased concentration of Amadorialbumin in type 1 diabetic patients was further increased in patients with early nephropathy (Schalkwijk et al. 1999). After adjustment for age, sex, duration of diabetes and serum creatinine, Amadori-albumin concentrations remained independently associated with nephropathy, indicating a direct pathogenic role for early glycation products in nephropathy. In addition, Amadori-albumin has been demonstrated in glomeruli of patients with diabetic nephropathy, and the degree of staining was increased with the severity of tissue damage (Sakai et al. 1996). These findings are consistent with a role of Amadori-albumin in the development of nephropathy. The first piece of evidence in this direction came from the demonstration that intravenous infusion of Amadori-albumin in animal models induced glomerular vasodilatation and hyperfiltration (Sabbatini et al. 1992) and resulted in renal glomerular changes such as diffuse thickening of the glomerular basement membrane (GBM). In agreement, treatment of $\mathrm{db} / \mathrm{db}$ mice with a monoclonal anti-Amadori albumin significantly reduced urinary protein excretion, renal type IV collagen and fibronectin mRNA levels and prevented the fourfold increase in volume of the mesangial matrix fraction (Cohen et al. 1994). This was confirmed in diabetic $\mathrm{db} / \mathrm{db}$ mice treated with a lowmolecular-weight compound that impedes the condensation of free glucose with lysine $\varepsilon$-amino groups in albumin (Cohen et al. 2000). Thus, Amadori-albumin has been implicated in the development of diabetic nephropathy.

Amadori-products have also been associated with diabetic retinopathy. The initial Amadori product of glycation on collagen is increased about threefold in type 1 diabetic patients and is further increased with the presence and severity of diabetic retinopathy and remained, after adjustment for age, sex and duration of diabetes, independently associated with retinopathy (McCance et al. 1993). We demonstrated the presence of Amadori-albumin in the retinal capillaries of diabetic patients with retinopathy (Schalkwijk et al. 1999). In diabetic db/db mice, the basement membrane thickening in the capillaries of the outer plexiform layer of retina from were ameliorated by treatment with A717 monoclonal antibody Amadorialbumin (Clements et al. 1998), indicating that Amadoriglycated albumin is directly involved in the pathogenesis of diabetic retinopathy.

Amadori-albumin may thus contribute to the pathogenesis of diabetic vascular disease. Prospective studies, however, are needed to determine whether increased plasma levels of Amadori-albumin in diabetic patients precede the development of diabetic complications. In addition, further studies are needed to unravel the intracellular signalling pathways which are involved in the biological action of Amadori-albumin. Agents that neutralise or prevent the formation of an excess of Amadori-glycated proteins in diabetes may offer a new therapy against early changes leading to diabetic vascular complications.

\section{AGEs and vascular complications}

Although Amadori-products are the major glycated modifications, so far most studies in vitro and in vivo have focused on the role of AGEs in diabetic complications.

\section{Biological effects of advanced glycation endproducts}

The accumulation of several AGEs in tissue proteins has been implicated in diabetic vascular complications, such as retinopathy, nephropathy and neuropathy, in atherosclerosis and age-related diseases such as in inflammation. At least three mechanisms have been proposed by which 
AGEs damage cells and tissues and contribute to the development of these complications: (1) the accumulation of AGEs in the extracellular matrix causing aberrant crosslinking, resulting in a decrease in the elasticity of vessels, (2) the binding of circulating AGEs to cellular receptors and activation of cell signalling pathways with subsequent modulation of gene expression and (3) intracellular glycation of proteins which may lead to impaired cell function.

\section{Accumulation of AGEs in the extracellular matrix}

Because of their slow turnover rate, structural components of the extracellular matrix are highly susceptible for glycation. Modest hyperglycaemia can even result in significant accumulation of AGEs on long-lived macromolecules (Vlassara et al. 1992). A common consequence of AGE accumulation on extracellular matrix proteins is the formation of cross-links. Complications of cross-link formation include decreased elasticity and increased stiffness of vessels, increased thickness and rigidity, narrowing of the vessel lumen (McNulty et al. 2007), development of sclerosis of renal glomeruli and atherosclerosis. Several studies have suggested that AGE cross-linking plays a role in increasing myocardial and vascular stiffness (Kass et al. 2001; Wolffenbuttel et al. 1998). A recent study found pentosidine levels to be associated with increased arterial stiffness and thickness (Yoshida et al. 2005) while another study suggested that an increase in the concentration of cross-link AGEs contributes to the stiffening of the aorta (Sims et al. 1996).

The AGE formation on extracellular matrix also interferes with matrix-cell interactions and disturbs biological attachment sites, which cause changes in signalling between the matrix and cells and disables cells to adhere to their substrates. AGE-induced changes in adhesion and spreading may be an important initial event in the pathogenesis of diabetic microangiopathy that contributes to cellular dysfunction and a disturbed functioning of blood vessels. For example, AGE modification of type IV collagen's binding cell-binding domain decreases endothelial cell adhesion (Haitoglou et al. 1992). Other long-lived proteins such as tubulin, myelin and lens crystallins are also target for glycation. AGE modification of lens crystallins contributes to cataract formation during ageing and diabetes. In addition, the composition of the extracellular matrix can be modified by AGEs by AGE-induced expression of extracellular matrix proteins (Throckmorton et al. 1995). Thus, the presence of AGEs on long-lived proteins may have deleterious pathological consequences by different mechanisms.
Intracellular glycation of proteins

Among all naturally occurring sugars, glucose has the slowest glycation rate. It has been shown that glucosederived glycolytic intermediates or intracellular sugars form much more glycated proteins and at a faster rate than do equimolar amounts of glucose. The glucose-derived glycolytic intermediate glucose-6-phosphate, the triose phosphates glyceraldehydes-3-phosphate and dihydroxyacetonphosphate and the dicarbonyl compounds glyoxal (GO), methylglyoxal (MGO) and 3-deoxyglucosone (3-DG) play an important role in the fast intracellular Maillard reaction (Thornalley 2005a). Therefore, intracellular AGE formation has gained an important role in the link between AGEs and diabetic complications. Indeed, it has been shown that intracellular AGEs are implicated in activating intracellular signalling pathways as well as in modifying the function of intracellular proteins, thereby contributing to diabetic vascular complications (Brownlee 2005).

The highly reactive dicarbonyl compound MGO has been identified as the major precursor in the formation of intracellular AGEs in endothelial cells (Shinohara et al. 1998; Miyata et al. 2001). In endothelial cells, basic fibroblast growth factor (bFGF) undergoes increased nonenzymatic glycation when exposed to hyperglycaemia resulting in an altered vascular function, including a reduced mitogenic activity of the endothelial cell (Giardino et al. 1994). Intracellular AGE formation also reduces the expression of endothelial NO synthase (eNOS) through increased eNOS mRNA degradation. In addition, studies have shown that AGEs quench NO and thereby directly lead to inactivation of NO. Reduced eNOS activity and inactivation of NO by AGEs may play an important role in the defective vasodilatory responses that occur in diabetes (Soro-Paavonen et al. 2010). AGEs also block the antiproliferative effects of $\mathrm{NO}$ on vascular smooth muscles cells, which subsequently contributes to atherosclerosis. It has been demonstrated that hyperglycaemia also alters mitochondrial function through glycation of mitochondrial proteins. MGO-induced modifications of specific mitochondrial proteins were detected in kidney of diabetic rats, which were paralleled by increases in superoxide formation by mitochondria (Rosca et al. 2005). In addition, antioxidant enzymes such as glutathione reductase and glutathione peroxidase are also modified by MGO, contributing to increased oxidative stress (Wu and Juurlink 2002). Other important enzymes, such as GAPDH, are modified by MGO, which in turn lead to inhibition of the enzyme activity (Lee et al. 2005). MGO also causes posttranslational modifications of regulatory proteins, thereby providing a mechanism for regulation of gene expression and modifying cellular functions (Yao et al. 2007). Recently, it 
has been shown that MGO modifies major proteasome proteins, resulting in impaired proteasome function (Queisser et al. 2010). We recently demonstrated in glyoxalase 1 overexpression rats that hyperglycaemia-induced impairment of endothelium-dependent vasorelaxation in diabetic rats is mediated by increased intracellular MGO levels in a pathway dependent on oxidative stress (Brouwers et al. 2010), underlining the importance of an increase in intracellular AGE formation for diabetic vascular complication.

\section{Binding of AGEs to cellular receptors}

The AGEs and AGE precursors such as dicarbonyl compounds can diffuse out of the cells and can modify circulating matrix proteins and proteins in the blood. Binding of circulating AGEs to different receptors on different cell types may lead to the activation of these receptors and subsequently activate key cell signalling pathways or to removal and break-down of circulating AGEs. A number of AGE-binding proteins have been identified, including macrophage scavenger receptors type I and II, oligosaccharyltransferase-48 (AGE-R1), 80K-H phosphoprotein (AGE-R2), galectin-3, CD36, LOX-170 and RAGE (Vlassara and Bucala 1996). So far, the functions of AGER1 and RAGE are studied in more detail.

AGE-R1 is a cell surface-associated receptor that opposes excessive ROS generation by AGEs. AGE-R1 is linked to the endocytosis and removal of AGEs ( $\mathrm{Lu}$ et al. 2004) and to the suppression of RAGE, MAPK, and NF-B activity, apparently via inhibition of AGE-induced ROS generation (Cai et al. 2008). Thus, AGE-R1 appears to control the activation of distinct cellular pathways and protects against vascular disease promoted by oxidants, such as via the AGE-RAGE axis (Cai et al. 2010).

RAGE is the best-characterised and the most-studied receptor for AGEs (Yan et al. 2010). RAGE is a multiligand receptor and a member of the immunoglobulin superfamily of cell surface molecules (Neeper et al. 1992; Schmidt et al. 1994). Activation of AGE-RAGE-induced signalling pathways causes modulation of gene expression of its target genes, which contribute to the development of vascular disease and diabetic complications. Among these, target genes are endothelin-1, vascular cell adhesion molecule-1, intercellular adhesion molecule-1, E-selectin, vascular endothelial growth factor (VEGF), inflammatory cytokines and growth factors (Goldin et al. 2006).

The first identified ligands for RAGE were AGEs, but it soon became evident that a number of other ligands also interact with RAGE including members of the S100/calgranulin family and high-mobility group box-1 (Bierhaus and Nawroth 2009).The structural diversity of RAGE ligands and the fact that RAGE recognises a class of ligands led to the hypothesis that RAGE is a pattern recognition receptor (Schmidt et al. 2001). RAGE is expressed in most tissues and is found on the cell surface of a variety of cells, including endothelial cells, mononuclear phagocytes, monocytes and macrophages, hepatocytes, smooth muscle cells, certain neurons, astrocytes, microglia, mesangial cells and podocytes. Under normal homeostasis, the expression of RAGE is low, while pathogenic conditions such as inflammation and diabetes, and at sites of accumulated AGEs in the vasculature, a sustained upregulation of RAGE has been shown.

Binding of AGEs to RAGE induces activation of multiple cellular signal transduction pathways, including activation of p21ras pathway and a cascade of MAPK (Schmidt et al. 1995, 1999). Activation of these MAPK results in nuclear translocation and activation of NF- $\kappa \mathrm{B}$ and subsequently to transcription of the target genes, including adhesion molecules and pro-inflammatory cytokines. One important facet of the AGE-RAGE axis is increased expression of RAGE itself and NF- $\kappa$ Bp 65 , thereby leading to a continued maintenance and amplification of the signalling pathways and inflammatory events (Bierhaus et al. 2001). In addition to activation of MAPK, a cdc42/rac pathway and JAK/STAT pathway are induced upon ligand engagement (Bierhaus et al. 2005). The diversity of signalling cascades identified in RAGE-mediated cellular signalling implies that different RAGE ligands might induce different pathways, especially in different cell types. Although multiple pathways downstream of RAGE have been identified, the proximal signalling proteins which actually bind to the receptor's cytosolic tail to initiate the signalling events have not yet been identified. Oligomerisation of RAGE seems to play a critical role in activation of RAGE and the induction of downstream signalling pathways. It has been shown that RAGE oligomerises on plasma membranes of human cells, and that this oligomerisation provides a mechanism to increase the number of binding sites and is required for high affinity binding of ligands (Xie et al. 2008).

The RAGE transgenic and knockout mice have also provided functional genomic models to identify the roles of RAGE in several disease states (Soro-Paavonen et al. 2008; Bierhaus et al. 2004; Wendt et al. 2003). Induction of diabetes in RAGE-deficient knockout mice confirms that RAGE contributes, at least partly, to the development of vascular complications and to the induction of inflammation. RAGE deficiency prevented diabetes-induced increases in renal mitochondrial superoxide production in hyperglycaemic environments and providing further evidence of a role for the AGE-RAGE pathway in the development and progression of diabetic vascular disease (Coughlan et al. 2009). Thus, a substantial number of in vitro and in vivo studies have demonstrated that activation of the AGE-RAGE axis plays an important role in vascular dysfunction and inflammation (Hudson et al. 2003). 


\section{Therapies interfering in the glycation pathway}

As described above, inhibition of Amadori-albumin formation, AGE formation and the AGE-RAGE axis as well as AGE cross-link breaking are potential targets for the treatment of diabetic complications (Fig. 2).

Inhibition of Amadori-albumin formation

Amadori-glycated albumin has been implicated in the development of diabetic nephropathy and retinopathy. This was confirmed in diabetic animal models treated with a low-molecular-weight compound (EXO-226) that impedes the condensation of free glucose with lysine $\varepsilon$-amino groups in albumin (Cohen et al. 2000). Administration of EXO-226 in diabetic animals normalised the plasma concentration of Amadori-albumin and reduced urinary albumin excretion and the overexpression of mRNA encoding for collagen (type IV) in the renal cortex as compared with their untreated diabetic controls.

GLY-230 (2-[3-chlorophenylamino]phenylacetic acid) is a new small molecule that inhibits modification of albumin by Amadori glucose adducts. In preclinical studies in diabetic animal models, GLY-230 significantly reduced Amadori-albumin, decreased urine albumin excretion, restored glomerular nephrin, downregulated TGF- $\beta_{1}$ and VEGF overexpression, ameliorated matrix accumulation, histomorphometric changes and the development of renal insufficiency as well as vitreous alterations (Cohen et al. 2002, 2005, 2007, 2008). A recent study in diabetic man demonstrated that GLY-230 lowers glycated albumin and that this decrease is associated with a reduction in urine albumin excretion in patients with pre-existing microalbuminuria (Kennedy et al. 2010).
On the basis of these data, neutralisation or inhibition of Amadori-albumin in diabetes may be a potential novel target for therapy against the development of diabetic vascular complications and encourage further evaluation of GLY-230 in diabetic renal dysfunction.

\section{Inhibition of AGE formation}

Aminoguanidine (Pimagedine) was the first AGE inhibitor studied (Brownlee et al. 1986). Randomised, placebocontrolled trials have evaluated aminoguanidine in patients with type 1 and 2 diabetes. In a phase III clinical trial in type 1 diabetic patients, aminoguanidine reduced proteinuria and progression of retinopathy, whereas the progression to overt nephropathy was not statistically improved (Bolton et al. 2004). This was the first clinical proof of the concept that inhibiting AGE formation can result in a clinically important attenuation of the serious complications of type 1 diabetes mellitus. However, a trial in 599 type 2 diabetic patients was discontinued due to safety concerns and lack of efficacy of aminoguanidine. Aminoguanidine is reported to have side effects in patients in the high-dose arm of the study, which include flu-like symptoms, abnormalities in liver function test, gastrointestinal disturbances, rare vasculitis and anaemia (Freedman et al. 1999). Despite the earlier promising results with aminoguanidine, it is unlikely to be used for therapeutic purposes.

Pyridoxamine, a vitamin B6 derivative, prevents the formation of AGEs from Amadori-intermediates (Khalifah et al. 2005) and cleaves 3-DG-reactive carbonyl intermediates (Chetyrkin et al. 2008). It inhibits the progression of renal disease and decreases hyperlipidemia and apparent redox imbalances in type 1 diabetic rats (Degenhardt et al. 2002). In phase II studies in patients with diabetic
Fig. 2 Potential sites of intervention in the formation of Amadori-modified proteins (GLY-230) and AGEs (aminoguanidine, pyridoxamine and benfotiamine), AGE crosslink breaking (ALT 711) and AGE-RAGE-mediated damage (sRAGE)

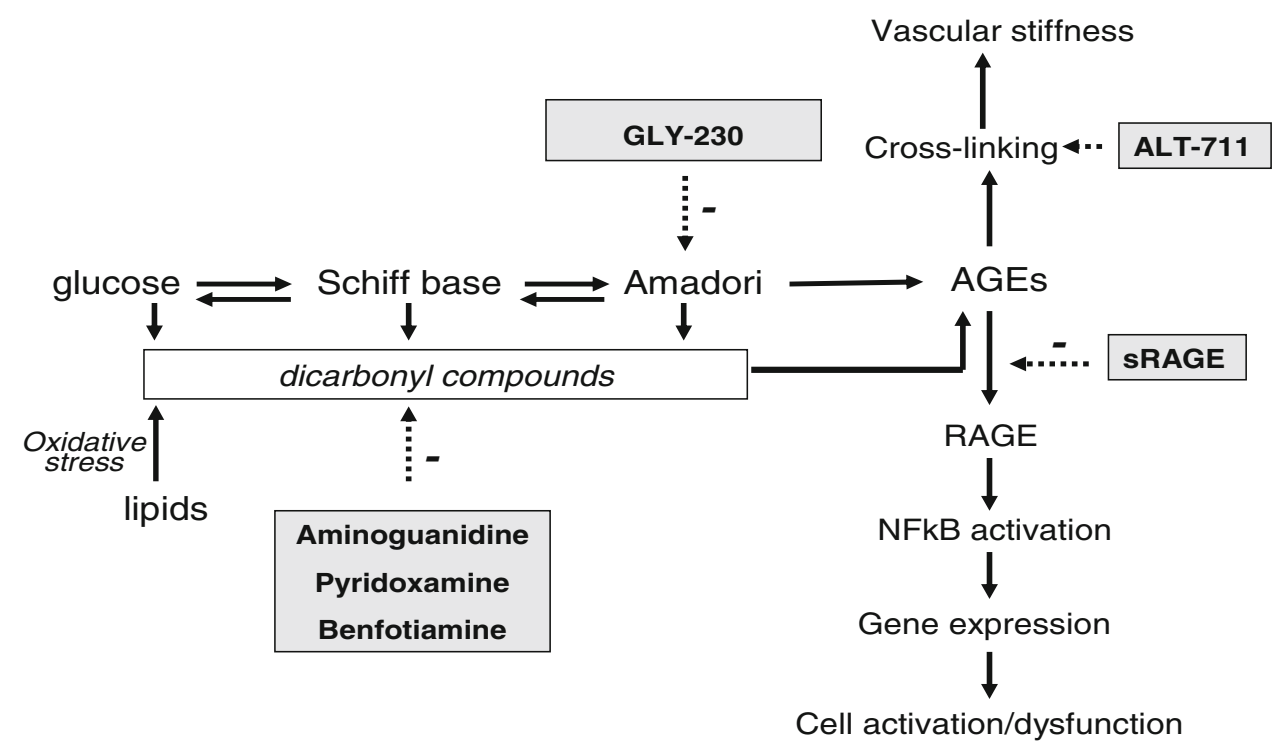


nephropathy, pyridoxamine significantly reduced the change from baseline in serum creatinine, whereas no differences in urinary albumin excretion were seen (Williams et al. 2007). In relation to derivatives of vitamin B6 such as pyridoxamine, recent research has indicated that vitamins B6, B9 and B12 co-therapy in diabetic nephropathy accelerates decline in renal function (House et al. 2010). However, it is unlikely that this effect is due to vitamin B6 and thereby compromises the use of pyridoxamine (Thornalley and Rabbani 2010).

Benfotiamine, a pro-drug of thiamine monophosphate, has AGE-lowering properties without decreasing early glycation adducts (Karachalias et al. 2010). Benfotiamine as well as thiamine reduces diabetic nephropathy and retinopathy in experimental animal models (Babaei-Jadidi et al. 2003; Hammes et al. 2003). It acts by correction of multiple pathways of biochemical dysfunction, and its major intervention in AGE formation at pharmacologically relevant concentrations in vivo is by preventing dicarbonyl formation (Thornalley 2005b). Administration of benfotiamine to type 2 diabetic patients, on a high AGE content diet, reduced circulating AGE levels and markers of oxidative stress (Stirban et al. 2006). In a pilot study, Brownlee and coworkers found that treatment with oral benfotiamine plus $\alpha$-lipoic acid normalises several complication-causing pathways in patients with type 1 diabetes (Du et al. 2008). In a pilot study in type 2 diabetic patients with microalbuminuria, high-dose thiamine therapy produced a regression of urinary albumin excretion (UAE) (Rabbani et al. 2009). However, a recent double-blind, randomised, placebo-controlled clinical trial on benfotiamine treatment in type 2 diabetic patients with nephropathy, high-dose benfotiamine treatment for 12 weeks as add-on to angiotensin converting enzyme inhibitors (ACEIs) or angiotensin receptor blockers (ARBs) did not reduce UAE despite improvement of thiamine status (Alkhalaf et al. 2010). It might be that thiamine derivatives provide protective effects in earlier stages of diabetic nephropathy. Therefore, long-term intervention studies and/or intervention studies in earlier stages of diabetic nephropathy are necessary to discern whether benfotiamine has the effect on the development of diabetic nephropathy.

The AGE inhibitors with structural features of aminoguanidine have been developed, including ALT-946 and OPB-9195. ALT-946 therapy reduces renal AGE accumulation and cortical tubular degeneration to a greater extent than aminoguanidine and, unlike aminoguanidine, reduces albumin excretion rate in the hypertensive transgenic (mRen-2)27 rat with streptozotocin-induced diabetes (Wilkinson-Berka et al. 2002). In another study, ALT-946 reduced equally albuminuria in a diabetic rat model either at the onset of diabetes or 16 weeks later (Forbes et al. 2001). No human data with this agent have been published.
OPB-9195, a thiazolidine derivative, is an agonist of the peroxisome proliferator-activated receptor. It inhibits glycoxidation and lipoxidation, thereby decreasing the formation of AGEs and dicarbonyl intermediates. OPB9195 prevented the progression of diabetic glomerular sclerosis in OLETF rats mainly by lowering serum levels of AGEs and attenuating AGE deposition in the glomeruli (Nakamura et al. 1997), most probably by scavenging dicarbonyl intermediates (Miyata et al. 1999). In strokeprone spontaneously hypertensive rats, OPB-9195 also slowed the progression of nephropathy, lowered blood pressure and reduced oxidative stress (Mizutani et al. 2002). This compound unfortunately traps pyridoxal-like aminoguanidine with an attendant toxicity, which has prevented its use in humans.

Aromatic compounds with AGE inhibitory effects have been developed, including LR-90 (Rahbar and Figarola 2003). LR-90 inhibits renal and circulating AGE accumulation through its potent metal chelating ability and its interaction with reactive carbonyl species (Figarola et al. 2003). Given to experimental models of both type 1 and type 2 diabetic nephropathy, it affords renoprotection such as improved albuminuria, glomerulosclerosis and tubulointerstitial fibrosis, concomitantly with a reduction of renal AGEs, TGF- $\beta 1$, connective tissue growth factor, fibronectin and collagen IV collagen deposition.

In a screening of a large chemical library of ca. 1,300 compounds, edaravone, a drug used to treat cerebral infarction, was discovered that had in vitro AGE inhibitory activity (Tsujita et al. 2004). Unfortunately, edaravone also traps pyridoxal, limiting thus its clinical usefulness. Taking advantage of edaravone's structure, a novel AGE inhibitor, TM2002, was synthesised, that does not trap pyridoxal (Izuhara et al. 2008). In vitro, TM2002 is a powerful AGE inhibitor. Like ARBs it also inhibits efficiently markers of oxidation, chelates transition metal, but does not bind to the angiotensin II type 1 receptor. It is readily bioavailable and non-toxic. In vivo, TM2002 given either acutely or for 8 weeks has no adverse effects. In four different rat models of renal injury and of cardiovascular injury, it improves renal and cardiovascular lesions without modification of blood pressure. Interestingly, it also decreased significantly infarct volume in both transient and permanent focal ischaemia rat models (Takizawa et al. 2007). TM2002 inhibition of advanced glycation and oxidative stress was confirmed by a significant reduction of the number of cells positive for AGEs and heme oxygenase- 1 and by a reduced level of protein carbonyl formation in parts of the brain. Like ARBs, but unlike aminoguanidine, OPB-9195, pyridoxamine and LR-90, TM2002 does not trap carbonyl precursors and belongs thus to a new class of AGE inhibitors. 
Inhibition of AGE formation by angiotensin receptor blockers

Renal protection of ARBs is usually explained exclusively by their blood pressure lowering action and by the inhibition of the renin angiotensin system. Recently, however, other pleiotropic actions of ARBs have been invoked. For example, we and others (Forbes et al. 2002; Miyata et al. 2002) reported that ARBs and ACEIs blocked the formation of AGEs through the reduction rather than through the entrapment of precursor carbonyl compounds. Interestingly, these inhibitory actions are not observed in other classes of anti-hypertensive agents, such as calcium channel blockers, diuretics and beta blockers (Izuhara et al. 2005). This finding fits with clinical experience that inhibitors of the RAS are better renoprotectors than other types of anti-hypertensive drugs (Wolf and Ritz 2005). In this model, the renal benefits of ARB appear independent of the effects on systemic blood pressure and on metabolic abnormalities. Of note, the amount of the renal pentosidine fell only with ARBs and correlated with the inhibition of proteinuria. The expression of markers of oxidative stress decreased in parallel with the reduction of AGEs.

In order to dissect the mechanisms of ARBs' protective benefits, a novel, non-toxic ARB derivative R-147176 was synthesised. R-147176 has a very weak affinity for the angiotensin II type 1 receptor, but a strong inhibition of oxidative stress and AGE formation (Izuhara et al. 2008). Despite a minimal effect on blood pressure, this compound provides a significant renoprotection in two different experimental type 2 diabetic rat models. Renal benefits of ARBs thus depend, at least partly, on their ability to inhibit oxidative stress and AGE formation. Of interest, R-147176, like ARBs, protected not only the kidney but also brain cells in an experimental rat stroke model (Takizawa et al. 2009).

\section{AGE breakers}

One of the consequences of AGE accumulation is increased cross-linking in cardiovascular tissue with a resulting increase in vascular stiffness. An increase in cardiovascular stiffness is known to be an important risk factor for cardiovascular mobility and mortality. In 1996, Alteon reported the first AGE cross-link breaker phenylthiazolium bromide (Vasan et al. 1996). Although this compound was not further developed because of the instability in aqueous solutions (Thornalley and Minhas 1999), studies with this compound provided a proof of concept that cross-link breakers are potential pharmacological drugs. Based on the experiences with this compound, the highly potent cross-link breaker ALT-711 was developed. However, it should be noted that Baynes and co-workers confirmed instability of phenylthiazolium bromide and also found similar instability for ALT-711 (Price et al. 2001). ALT-711 (alagebrium) is a small easily synthesised compound (3-phenacyl-4,5-dimethylthiazolium chloride) and is the first drug in a new class of thiazolium therapeutic agents that break established AGE cross-links between proteins. ALT-711 is being developed for cardiovascular diseases including systolic hypertension. ALT711 is effective in reducing large artery stiffness, slowing pulse-wave velocity, enhancing cardiac output, left ventricular mass, cardiac expression of brain natriuretic peptide and improving left ventricular diastolic distensibility (Asif et al. 2000; Wolffenbuttel et al. 1998; Little et al. 2005). Additionally, in experimental diabetes, ALT-711 treatment attenuated atherosclerosis (Forbes et al. 2004) and diabetic nephropathy (Thallas-Bonke et al. 2004). The effect was not only on the reduction of renal AGEs but also on putative mediators of renal injury, such as prosclerotic cytokines, protein kinase $\mathrm{C}$ and oxidative stress. ALT-711 is the only AGE-cross-link breaker in advanced human testing.

\section{RAGE antagonist}

Studies performed in vitro and in vivo revealed the AGERAGE axis as one of the major accounts in the development of diabetic vascular complications. The AGE-RAGE axis would thus be considered as a candidate molecular target for overcoming diabetic vascular complications. This concept is supported by the observation that low-molecular-weight heparin functions as an antagonist of RAGE and prevents diabetic nephropathy (Myint et al. 2006).

Thiazolidinediones (TZDs) are ligands of the peroxisome proliferator-activated receptor-gamma (PPARgamma); TZDs, such as rosiglitazone (Wang et al. 2006), have also been recently identified as RAGE antagonists. They exert beneficial effects in diabetic nephropathy independently of insulin sensitisation. Interestingly, rosiglitazone administered to type 2 diabetic subjects increased the serum level of protective sRAGEs besides the decrease of circulating AGE levels (Tan et al. 2007).

Studies with RAGE knockout mice that do not express sRAGE or full-length RAGE suggest that sRAGE acts via inhibition of RAGE-dependent phenomena (Bierhaus et al. 2005). Recently, it has been postulated that ACE inhibition reduces the accumulation of $\mathrm{AGE}$ in diabetes partly through an increased production and secretion of sRAGE into the plasma (Forbes et al. 2005). It remains to be seen whether sRAGE acts as an antagonist inhibiting the RAGEdependent signalling pathways, or as a binder of various RAGE ligands such as AGEs. sRAGE or possibly a nonpeptide RAGE antagonist may thus become a future therapeutic target (Goh and Cooper 2008). 


\section{Conclusion}

A growing body of evidence demonstrates a role of nonenzymatic glycation in the development of diabetic vascular complications including diabetic nephropathy and retinopathy. Several agents interfering with the glycation pathway have protected the organs in experimental diabetic models. Some of these agents, tested in human clinical studies, open encouraging new therapeutic avenues.

Open Access This article is distributed under the terms of the Creative Commons Attribution Noncommercial License which permits any noncommercial use, distribution, and reproduction in any medium, provided the original author(s) and source are credited.

\section{References}

Alkhalaf A, Klooster A, van Oeveren W, Achenbach U, Kleefstra N, Slingerland RJ, Mijnhout GS, Bilo HJ, Gans RO, Navis GJ, Bakker SJ (2010) A double-blind, randomized, placebo-controlled clinical trial on benfotiamine treatment in patients with diabetic nephropathy. Diabetes Care 33(7):1598-1601

Amore A, Cirina P, Mitola S, Peruzzi L, Gianoglio B, Rabbone I, Sacchetti C, Cerutti F, Grillo C, Coppo R (1997) Nonenzymatically glycated albumin (Amadori adducts) enhances nitric oxide synthase activity and gene expression in endothelial cells. Kidney Int 51:27-35

Asif M, Egan J, Vasan S, Jyothirmayi GN, Masurekar MR, Lopez S, Williams C, Torres RL, Wagle D, Ulrich P, Cerami A, Brines M, Regan TJ (2000) An advanced glycation endproduct cross-link breaker can reverse age-related increases in myocardial stiffness. Proc Natl Acad Sci USA 97:2809-2813

Babaei-Jadidi R, Karachalias N, Ahmed N, Battah S, Thornalley PJ (2003) Prevention of incipient diabetic nephropathy by highdose thiamine and benfotiamine. Diabetes 52:2110-2120

Baynes JW, Thorpe SR (2000) Glycoxidation and lipoxidation in atherogenesis. Free Radic Biol Med 28:1708-1716

Bierhaus A, Nawroth PP (2009) Multiple levels of regulation determine the role of the receptor for AGE (RAGE) as common soil in inflammation, immune responses and diabetes mellitus and its complications. Diabetologia 52:2251-2263

Bierhaus A, Schiekofer S, Schwaninger M, Andrassy M, Humpert PM, Chen J, Hong M, Luther T, Henle T, Kloting I, Morcos M, Hofmann M, Tritschler H, Weigle B, Kasper M, Smith M, Perry G, Schmidt AM, Stern DM, Haring HU, Schleicher E, Nawroth PP (2001) Diabetes-associated sustained activation of the transcription factor nuclear factor-kappaB. Diabetes 50:27922808

Bierhaus A, Haslbeck KM, Humpert PM, Liliensiek B, Dehmer T, Morcos M, Sayed AA, Andrassy M, Schiekofer S, Schneider JG, Schulz JB, Heuss D, Neundorfer B, Dierl S, Huber J, Tritschler H, Schmidt AM, Schwaninger M, Haering HU, Schleicher E, Kasper M, Stern DM, Arnold B, Nawroth PP (2004) Loss of pain perception in diabetes is dependent on a receptor of the immunoglobulin superfamily. J Clin Invest 114:1741-1751

Bierhaus A, Humpert PM, Morcos M, Wendt T, Chavakis T, Arnold B, Stern DM, Nawroth PP (2005) Understanding RAGE, the receptor for advanced glycation end products. J Mol Med 83:876-886

Bolton WK, Cattran DC, Williams ME, Adler SG, Appel GB, Cartwright K, Foiles PG, Freedman BI, Raskin P, Ratner RE, Spinowitz BS, Whittier FC, Wuerth JP (2004) Randomized trial of an inhibitor of formation of advanced glycation end products in diabetic nephropathy. Am J Nephrol 24:32-40

Brouwers O, Niessen PM, Haenen G, Miyata T, Brownlee M, Stehouwer CD, De Mey JG, Schalkwijk CG (2010) Hyperglycaemia-induced impairment of endothelium-dependent vasorelaxation in rat mesenteric arteries is mediated by intracellular methylglyoxal levels in a pathway dependent on oxidative stress. Diabetologia 53:989-1000

Brownlee M (2005) The pathobiology of diabetic complications: a unifying mechanism. Diabetes 54:1615-1625

Brownlee M, Vlassara H, Kooney A, Ulrich P, Cerami A (1986) Aminoguanidine prevents diabetes-induced arterial wall protein cross-linking. Science 232:1629-1632

Cai W, He JC, Zhu L, Chen X, Striker GE, Vlassara H (2008) AGEreceptor-1 counteracts cellular oxidant stress induced by AGEs via negative regulation of p66shc-dependent FKHRL1 phosphorylation. Am J Physiol Cell Physiol 294:C145-C152

Cai W, Torreggiani M, Zhu L, Chen X, He JC, Striker GE, Vlassara H (2010) AGER1 regulates endothelial cell NADPH oxidasedependent oxidant stress via PKC-delta: implications for vascular disease. Am J Physiol Cell Physiol 298:C624-C634

Chen S, Jim B, Ziyadeh FN (2003) Diabetic nephropathy and transforming growth factor-beta: transforming our view of glomerulosclerosis and fibrosis build-up. Semin Nephrol 23:532-543

Chetyrkin SV, Zhang W, Hudson BG, Serianni AS, Voziyan PA (2008) Pyridoxamine protects proteins from functional damage by 3-deoxyglucosone: mechanism of action of pyridoxamine. Biochemistry 47:997-1006

Cines DB, Pollak ES, Buck CA, Loscalzo J, Zimmerman GA, McEver RP, Pober JS, Wick TM, Konkle BA, Schwartz BS, Barnathan ES, McCrae KR, Hug BA, Schmidt AM, Stern DM (1998) Endothelial cells in physiology and in the pathophysiology of vascular disorders. Blood 91:3527-3561

Clements RS Jr, Robison WG Jr, Cohen MP (1998) Anti-glycated albumin therapy ameliorates early retinal microvascular pathology in $\mathrm{db} / \mathrm{db}$ mice. J Diabetes Complications 12:28-33

Cohen MP, Hud E, Wu VY (1994) Amelioration of diabetic nephropathy by treatment with monoclonal antibodies against glycated albumin. Kidney Int 45:1673-1679

Cohen MP, Clements RS, Cohen JA, Shearman CW (1996) Glycated albumin promotes a generalized vasculopathy in the $\mathrm{db} / \mathrm{db}$ mouse. Biochem Biophys Res Commun 218:72-75

Cohen MP, Masson N, Hud E, Ziyadeh F, Han DC, Clements RS (2000) Inhibiting albumin glycation ameliorates diabetic nephropathy in the db/db mouse. Exp Nephrol 8:135-143

Cohen MP, Ziyadeh FN, Hong SW, Shearman CW, Hud E, Lautenslager GT, Iglesias-de la Cruz MC, Chen S (2002) Inhibiting albumin glycation in vivo ameliorates glomerular overexpression of TGF-beta1. Kidney Int 61:2025-2032

Cohen MP, Chen S, Ziyadeh FN, Shea E, Hud EA, Lautenslager GT, Shearman CW (2005) Evidence linking glycated albumin to altered glomerular nephrin and VEGF expression, proteinuria, and diabetic nephropathy. Kidney Int 68:1554-1561

Cohen MP, Lautenslager GT, Hud E, Shea E, Wang A, Chen S, Shearman CW (2007) Inhibiting albumin glycation attenuates dysregulation of VEGFR-1 and collagen IV subchain production and the development of renal insufficiency. Am J Physiol Renal Physiol 292:F789-F795

Cohen MP, Hud E, Wu VY, Shearman CW (2008) Amelioration of diabetes-associated abnormalities in the vitreous fluid by an inhibitor of albumin glycation. Invest Ophthalmol Vis Sci 49:5089-5093

Coughlan MT, Thorburn DR, Penfold SA, Laskowski A, Harcourt BE, Sourris KC, Tan AL, Fukami K, Thallas-Bonke V, Nawroth PP, Brownlee M, Bierhaus A, Cooper ME, Forbes JM (2009) 
RAGE-induced cytosolic ROS promote mitochondrial superoxide generation in diabetes. J Am Soc Nephrol 20:742-752

Degenhardt TP, Alderson NL, Arrington DD, Beattie RJ, Basgen JM, Steffes MW, Thorpe SR, Baynes JW (2002) Pyridoxamine inhibits early renal disease and dyslipidemia in the streptozotocin-diabetic rat. Kidney Int 61:939-950

Dolhofer R, Wieland OH (1980) Increased glycosylation of serum albumin in diabetes mellitus. Diabetes 29:417-422

Du X, Edelstein D, Brownlee M (2008) Oral benfotiamine plus alphalipoic acid normalises complication-causing pathways in type 1 diabetes. Diabetologia 51:1930-1932

Figarola JL, Scott S, Loera S, Tessler C, Chu P, Weiss L, Hardy J, Rahbar S (2003) LR-90 a new advanced glycation endproduct inhibitor prevents progression of diabetic nephropathy in streptozotocin-diabetic rats. Diabetologia 46:1140-1152

Forbes JM, Soulis T, Thallas V, Panagiotopoulos S, Long DM, Vasan S, Wagle D, Jerums G, Cooper ME (2001) Renoprotective effects of a novel inhibitor of advanced glycation. Diabetologia 44:108-114

Forbes JM, Cooper ME, Thallas V, Burns WC, Thomas MC, Brammar GC, Lee F, Grant SL, Burrell LA, Jerums G, Osicka TM (2002) Reduction of the accumulation of advanced glycation end products by ACE inhibition in experimental diabetic nephropathy. Diabetes 51:3274-3282

Forbes JM, Yee LT, Thallas V, Lassila M, Candido R, JandeleitDahm KA, Thomas MC, Burns WC, Deemer EK, Thorpe SM, Cooper ME, Allen TJ (2004) Advanced glycation end product interventions reduce diabetes-accelerated atherosclerosis. Diabetes 53:1813-1823

Forbes JM, Thorpe SR, Thallas-Bonke V, Pete J, Thomas MC, Deemer ER, Bassal S, El Osta A, Long DM, Panagiotopoulos S, Jerums G, Osicka TM, Cooper ME (2005) Modulation of soluble receptor for advanced glycation end products by angiotensin converting enzyme-1 inhibition in diabetic nephropathy. J Am Soc Nephrol 16(8):2363-2672

Freedman BI, Wuerth JP, Cartwright K, Bain RP, Dippe S, Hershon K, Mooradian AD, Spinowitz BS (1999) Design and baseline characteristics for the aminoguanidine Clinical Trial in Overt Type 2 Diabetic Nephropathy (ACTION II). Control Clin Trials 20:493-510

Genuth S, Sun W, Cleary P, Sell DR, Dahms W, Malone J, Sivitz W, Monnier VM (2005) Glycation and carboxymethyllysine levels in skin collagen predict the risk of future 10-year progression of diabetic retinopathy and nephropathy in the diabetes control and complications trial and epidemiology of diabetes interventions and complications participants with type 1 diabetes. Diabetes 54:3103-3111

Giardino I, Edelstein D, Brownlee M (1994) Nonenzymatic glycosylation in vitro and in bovine endothelial cells alters basic fibroblast growth factor activity. A model for intracellular glycosylation in diabetes. J Clin Invest 94:110-117

Goh SY, Cooper ME (2008) Clinical review: the role of advanced glycation end products in progression and complications of diabetes. J Clin Endocrinol Metab 93:1143-1152

Goldin A, Beckman JA, Schmidt AM, Creager MA (2006) Advanced glycation end products: sparking the development of diabetic vascular injury. Circulation 114:597-605

Haitoglou CS, Tsilibary EC, Brownlee M, Charonis AS (1992) Altered cellular interactions between endothelial cells and nonenzymatically glucosylated laminin/type IV collagen. J Biol Chem 267:12404-12407

Hammes HP, Du X, Edelstein D, Taguchi T, Matsumura T, Ju Q, Lin J, Bierhaus A, Nawroth P, Hannak D, Neumaier M, Bergfeld R, Giardino I, Brownlee M (2003) Benfotiamine blocks three major pathways of hyperglycemic damage and prevents experimental diabetic retinopathy. Nat Med 9:294-299
Hattori Y, Suzuki M, Hattori S, Kasai K (2002) Vascular smooth muscle cell activation by glycated albumin (Amadori adducts). Hypertension 39:22-28

Higai K, Shimamura A, Matsumoto K (2006) Amadori-modified glycated albumin predominantly induces E-selectin expression on human umbilical vein endothelial cells through NADPH oxidase activation. Clin Chim Acta 367:137-143

House AA, Eliasziw M, Cattran DC, Churchill DN, Oliver MJ, Fine A, Dresser GK, Spence JD (2010) Effect of B-vitamin therapy on progression of diabetic nephropathy: a randomized controlled trial. JAMA 303:1603-1609

Hudson BI, Bucciarelli LG, Wendt T, Sakaguchi T, Lalla E, Qu W, Lu Y, Lee L, Stern DM, Naka Y, Ramasamy R, Yan SD, Yan SF, D'Agati V, Schmidt AM (2003) Blockade of receptor for advanced glycation endproducts: a new target for therapeutic intervention in diabetic complications and inflammatory disorders. Arch Biochem Biophys 419:80-88

Izuhara Y, Nangaku M, Inagi R, Tominaga N, Aizawa T, Kurokawa K, Miyata T, van Ypersele DS (2005) Renoprotective properties of angiotensin receptor blockers beyond blood pressure lowering. J Am Soc Nephrol 16:3631-3641

Izuhara Y, Nangaku M, Takizawa S, Takahashi S, Shao J, Oishi H, Kobayashi H, van Ypersele DS, Miyata T (2008) A novel class of advanced glycation inhibitors ameliorates renal and cardiovascular damage in experimental rat models. Nephrol Dial Transplant 23:497-509

Jaleel A, Halvatsiotis P, Williamson B, Juhasz P, Martin S, Nair KS (2005) Identification of Amadori-modified plasma proteins in type 2 diabetes and the effect of short-term intensive insulin treatment. Diabetes Care 28:645-652

Karachalias N, Babaei-Jadidi R, Rabbani N, Thornalley PJ (2010) Increased protein damage in renal glomeruli, retina, nerve, plasma and urine and its prevention by thiamine and benfotiamine therapy in a rat model of diabetes. Diabetologia 53:1506-1516

Kass DA, Shapiro EP, Kawaguchi M, Capriotti AR, Scuteri A, de Groof RC, Lakatta EG (2001) Improved arterial compliance by a novel advanced glycation end-product crosslink breaker. Circulation 104:1464-1470

Kennedy L, Solano MP, Meneghini L, Lo M, Cohen MP (2010) Antiglycation and anti-albuminuric effects of GLY-230 in human diabetes. Am J Nephrol 31:110-116

Khalifah RG, Chen Y, Wassenberg JJ (2005) Post-Amadori AGE inhibition as a therapeutic target for diabetic complications: a rational approach to second-generation Amadorin design. Ann N Y Acad Sci 1043:793-806

Lee HJ, Howell SK, Sanford RJ, Beisswenger PJ (2005) Methylglyoxal can modify GAPDH activity and structure. Ann N Y Acad Sci 1043:135-145

Little WC, Zile MR, Kitzman DW, Hundley WG, O'Brien TX, de Groof RC (2005) The effect of alagebrium chloride (ALT-711), a novel glucose cross-link breaker, in the treatment of elderly patients with diastolic heart failure. J Card Fail 11:191-195

Lu C, He JC, Cai W, Liu H, Zhu L, Vlassara H (2004) Advanced glycation endproduct (AGE) receptor 1 is a negative regulator of the inflammatory response to AGE in mesangial cells. Proc Natl Acad Sci USA 101:11767-11772

McCance DR, Dyer DG, Dunn JA, Bailie KE, Thorpe SR, Baynes JW, Lyons TJ (1993) Maillard reaction products and their relation to complications in insulin-dependent diabetes mellitus. J Clin Invest 91:2470-2478

McNulty M, Mahmud A, Feely J (2007) Advanced glycation endproducts and arterial stiffness in hypertension. Am J Hypertens 20:242-247

Miyata T, Ishikawa S, Asahi K, Inagi R, Suzuki D, Horie K, Tatsumi K, Kurokawa K (1999) 2-Isopropylidenehydrazono-4-oxo- 
thiazolidin-5-ylacetanilide (OPB-9195) treatment inhibits the development of intimal thickening after balloon injury of rat carotid artery: role of glycoxidation and lipoxidation reactions in vascular tissue damage. FEBS Lett 445:202-206

Miyata T, van Ypersele DS, Imasawa T, Yoshino A, Ueda Y, Ogura H, Kominami K, Onogi H, Inagi R, Nangaku M, Kurokawa K (2001) Glyoxalase I deficiency is associated with an unusual level of advanced glycation end products in a hemodialysis patient. Kidney Int 60:2351-2359

Miyata T, van Ypersele DS, Ueda Y, Ichimori K, Inagi R, Onogi H, Ishikawa N, Nangaku M, Kurokawa K (2002) Angiotensin II receptor antagonists and angiotensin-converting enzyme inhibitors lower in vitro the formation of advanced glycation end products: biochemical mechanisms. J Am Soc Nephrol 13:2478-2487

Mizutani K, Ikeda K, Tsuda K, Yamori Y (2002) Inhibitor for advanced glycation end products formation attenuates hypertension and oxidative damage in genetic hypertensive rats. J Hypertens 20:1607-1614

Myint KM, Yamamoto Y, Doi T, Kato I, Harashima A, Yonekura H, Watanabe T, Shinohara H, Takeuchi M, Tsuneyama K, Hashimoto N, Asano M, Takasawa S, Okamoto H, Yamamoto H (2006) RAGE control of diabetic nephropathy in a mouse model: effects of RAGE gene disruption and administration of low-molecular weight heparin. Diabetes 55:2510-2522

Nakamura S, Makita Z, Ishikawa S, Yasumura K, Fujii W, Yanagisawa K, Kawata T, Koike T (1997) Progression of nephropathy in spontaneous diabetic rats is prevented by OPB9195, a novel inhibitor of advanced glycation. Diabetes 46:895-899

Neeper M, Schmidt AM, Brett J, Yan SD, Wang F, Pan YC, Elliston K, Stern D, Shaw A (1992) Cloning and expression of a cell surface receptor for advanced glycosylation end products of proteins. J Biol Chem 267:14998-15004

Price DL, Rhett PM, Thorpe SR, Baynes JW (2001) Chelating activity of advanced glycation end-product inhibitors. J Biol Chem 276:48967-48972

Queisser MA, Yao D, Geisler S, Hammes HP, Lochnit G, Schleicher ED, Brownlee M, Preissner KT (2010) Hyperglycemia impairs proteasome function by methylglyoxal. Diabetes 59:670-678

Rabbani N, Alam SS, Riaz S, Larkin JR, Akhtar MW, Shafi T, Thornalley PJ (2009) High-dose thiamine therapy for patients with type 2 diabetes and microalbuminuria: a randomised, double-blind placebo-controlled pilot study. Diabetologia 52:208-212

Rahbar S, Figarola JL (2003) Novel inhibitors of advanced glycation endproducts. Arch Biochem Biophys 419:63-79

Rosca MG, Mustata TG, Kinter MT, Ozdemir AM, Kern TS, Szweda LI, Brownlee M, Monnier VM, Weiss MF (2005) Glycation of mitochondrial proteins from diabetic rat kidney is associated with excess superoxide formation. Am J Physiol Renal Physiol 289:F420-F430

Sabbatini M, Sansone G, Uccello F, Giliberti A, Conte G, Andreucci VE (1992) Early glycosylation products induce glomerular hyperfiltration in normal rats. Kidney Int 42:875-881

Sakai H, Jinde K, Suzuki D, Yagame M, Nomoto Y (1996) Localization of glycated proteins in the glomeruli of patients with diabetic nephropathy. Nephrol Dial Transplant 11(Suppl 5):66-71

Schalkwijk CG, Stehouwer CD (2005) Vascular complications in diabetes mellitus: the role of endothelial dysfunction. Clin Sci 109:143-159

Schalkwijk CG, Ligtvoet N, Twaalfhoven H, Jager A, Blaauwgeers HG, Schlingemann RO, Tarnow L, Parving HH, Stehouwer CD, van Hinsbergh VW (1999) Amadori albumin in type 1 diabetic patients: correlation with markers of endothelial function, association with diabetic nephropathy, and localization in retinal capillaries. Diabetes 48:2446-2453

Schmidt AM, Hasu M, Popov D, Zhang JH, Chen J, Yan SD, Brett J, Cao R, Kuwabara K, Costache G (1994) Receptor for advanced glycation end products (AGEs) has a central role in vessel wall interactions and gene activation in response to circulating AGE proteins. Proc Natl Acad Sci USA 91:8807-8811

Schmidt AM, Hori O, Chen JX, Li JF, Crandall J, Zhang J, Cao R, Yan SD, Brett J, Stern D (1995) Advanced glycation endproducts interacting with their endothelial receptor induce expression of vascular cell adhesion molecule-1 (VCAM-1) in cultured human endothelial cells and in mice. A potential mechanism for the accelerated vasculopathy of diabetes. J Clin Invest 96:1395-1403

Schmidt AM, Yan SD, Wautier JL, Stern D (1999) Activation of receptor for advanced glycation end products: a mechanism for chronic vascular dysfunction in diabetic vasculopathy and atherosclerosis. Circ Res 19(84):489-497

Schmidt AM, Yan SD, Yan SF, Stern DM (2001) The multiligand receptor RAGE as a progression factor amplifying immune and inflammatory responses. J Clin Invest 108:949-955

Shinohara M, Thornalley PJ, Giardino I, Beisswenger P, Thorpe SR, Onorato J, Brownlee M (1998) Overexpression of glyoxalase-I in bovine endothelial cells inhibits intracellular advanced glycation endproduct formation and prevents hyperglycemia-induced increases in macromolecular endocytosis. J Clin Invest 101:1142-1147

Sims TJ, Rasmussen LM, Oxlund H, Bailey AJ (1996) The role of glycation cross-links in diabetic vascular stiffening. Diabetologia 39:946-951

Skyler JS, Bergenstal R, Bonow RO, Buse J, Deedwania P, Gale EA, Howard BV, Kirkman MS, Kosiborod M, Reaven P, Sherwin RS (2009) Intensive glycemic control and the prevention of cardiovascular events: implications of the ACCORD, ADVANCE, and VA Diabetes Trials: a position statement of the American Diabetes Association and a Scientific Statement of the American College of Cardiology Foundation and the American Heart Association. J Am Coll Cardiol 53:298-304

Soro-Paavonen A, Watson AM, Li J, Paavonen K, Koitka A, Calkin AC, Barit D, Coughlan MT, Drew BG, Lancaster GI, Thomas M, Forbes JM, Nawroth PP, Bierhaus A, Cooper ME, JandeleitDahm KA (2008) Receptor for advanced glycation end products (RAGE) deficiency attenuates the development of atherosclerosis in diabetes. Diabetes 57:2461-2469

Soro-Paavonen A, Zhang WZ, Venardos K, Coughlan MT, Harris E, Tong DC, Brasacchio D, Paavonen K, Chin-Dusting J, Cooper ME, Kaye D, Thomas MC, Forbes JM (2010) Advanced glycation end-products induce vascular dysfunction via resistance to nitric oxide and suppression of endothelial nitric oxide synthase. J Hypertens 28(4):780-788

Stirban A, Negrean M, Stratmann B, Gawlowski T, Horstmann T, Gotting C, Kleesiek K, Mueller-Roesel M, Koschinsky T, Uribarri J, Vlassara H, Tschoepe D (2006) Benfotiamine prevents macro- and microvascular endothelial dysfunction and oxidative stress following a meal rich in advanced glycation end products in individuals with type 2 diabetes. Diabetes Care 29:2064-2071

Takizawa S, Izuhara Y, Kitao Y, Hori O, Ogawa S, Morita Y, Takagi S, van Ypersele DS, Miyata T (2007) A novel inhibitor of advanced glycation and endoplasmic reticulum stress reduces infarct volume in rat focal cerebral ischemia. Brain Res 1183:124-137

Takizawa S, Dan T, Uesugi T, Nagata E, Takagi S, van Ypersele DS, Miyata T (2009) A sartan derivative with a very low angiotensin II receptor affinity ameliorates ischemic cerebral damage. J Cereb Blood Flow Metab 29:1665-1672 
Tan KC, Chow WS, Tso AW, Xu A, Tse HF, Hoo RL, Betteridge DJ, Lam KS (2007) Thiazolidinedione increases serum soluble receptor for advanced glycation end-products in type 2 diabetes. Diabetologia 50:1819-1825

Thallas-Bonke V, Lindschau C, Rizkalla B, Bach LA, Boner G, Meier M, Haller H, Cooper ME, Forbes JM (2004) Attenuation of extracellular matrix accumulation in diabetic nephropathy by the advanced glycation end product cross-link breaker ALT-711 via a protein kinase C-alpha-dependent pathway. Diabetes 53:2921-2930

The Diabetes Control Complications Trial Research Group (1993) The effect of intensive treatment of diabetes on the development and progression of long-term complications in insulin-dependent diabetes mellitus. The Diabetes Control and Complications Trial Research Group. N Engl J Med 329:977-986

The Diabetes Control and Complications Trial/Epidemiology of Diabetes Interventions and Complications Research Group (2000) Retinopathy and nephropathy in patients with type 1 diabetes four years after a trial of intensive therapy. The Diabetes Control and Complications Trial/Epidemiology of Diabetes Interventions and Complications Research Group. N Engl J Med 342:381-389

Thornalley PJ (2005a) Dicarbonyl intermediates in the maillard reaction. Ann N Y Acad Sci 1043:111-117

Thornalley PJ (2005b) The potential role of thiamine (vitamin B1) in diabetic complications. Curr Diabetes Rev 1:287-298

Thornalley PJ, Minhas HS (1999) Rapid hydrolysis and slow alpha, beta-dicarbonyl cleavage of an agent proposed to cleave glucosederived protein cross-links. Biochem Pharmacol 57:303-307

Thornalley PJ, Rabbani N (2010) Therapy: Vitamin B(6), B(9) and $\mathrm{B}(12)$ in diabetic nephropathy-beware. Nat Rev Endocrinol 6:477-478

Throckmorton DC, Brogden AP, Min B, Rasmussen H, Kashgarian M (1995) PDGF and TGF-beta mediate collagen production by mesangial cells exposed to advanced glycosylation end products. Kidney Int 48:111-117

Tsujita K, Shimomura H, Kawano H, Hokamaki J, Fukuda M, Yamashita T, Hida S, Nakamura Y, Nagayoshi Y, Sakamoto T, Yoshimura M, Arai H, Ogawa H (2004) Effects of edaravone on reperfusion injury in patients with acute myocardial infarction. Am J Cardiol 94:481-484

UK Prospective Diabetes Study (UKPDS) Group (1995) Relative efficacy of randomly allocated diet, sulphonylurea, insulin, or metformin in patients with newly diagnosed non-insulin dependent diabetes followed for three years (UKPDS 13). BMJ 310:83-88

UK Prospective Diabetes Study (UKPDS) Group (1998) Intensive blood-glucose control with sulphonylureas or insulin compared with conventional treatment and risk of complications in patients with type 2 diabetes (UKPDS 33). Lancet 352:837-853

Vasan S, Zhang X, Zhang X, Kapurniotu A, Bernhagen J, Teichberg S, Basgen J, Wagle D, Shih D, Terlecky I, Bucala R, Cerami A, Egan J, Ulrich P (1996) An agent cleaving glucose-derived protein crosslinks in vitro and in vivo. Nature 382:275-278

Vlassara H, Bucala R (1996) Recent progress in advanced glycation and diabetic vascular disease: role of advanced glycation end product receptors. Diabetes 45(Suppl 3):S65-S66

Vlassara H, Fuh H, Makita Z, Krungkrai S, Cerami A, Bucala R (1992) Exogenous advanced glycosylation end products induce complex vascular dysfunction in normal animals: a model for diabetic and aging complications. Proc Natl Acad Sci USA 89:12043-12047

Wang K, Zhou Z, Zhang M, Fan L, Forudi F, Zhou X, Qu W, Lincoff AM, Schmidt AM, Topol EJ, Penn MS (2006) Peroxisome proliferator-activated receptor gamma down-regulates receptor for advanced glycation end products and inhibits smooth muscle cell proliferation in a diabetic and nondiabetic rat carotid artery injury model. J Pharmacol Exp Ther 317:37-43

Wendt TM, Tanji N, Guo J, Kislinger TR, Qu W, Lu Y, Bucciarelli LG, Rong LL, Moser B, Markowitz GS, Stein G, Bierhaus A, Liliensiek B, Arnold B, Nawroth PP, Stern DM, D'Agati VD, Schmidt AM (2003) RAGE drives the development of glomerulosclerosis and implicates podocyte activation in the pathogenesis of diabetic nephropathy. Am J Pathol 162:1123-1137

Wilkinson-Berka JL, Kelly DJ, Koerner SM, Jaworski K, Davis B, Thallas V, Cooper ME (2002) ALT-946 and aminoguanidine, inhibitors of advanced glycation, improve severe nephropathy in the diabetic transgenic (mREN-2)27 rat. Diabetes 51:3283-3289

Williams ME, Bolton WK, Khalifah RG, Degenhardt TP, Schotzinger RJ, McGill JB (2007) Effects of pyridoxamine in combined phase 2 studies of patients with type 1 and type 2 diabetes and overt nephropathy. Am J Nephrol 27:605-614

Wolf G, Ritz E (2005) Combination therapy with ACE inhibitors and angiotensin II receptor blockers to halt progression of chronic renal disease: pathophysiology and indications. Kidney Int 67:799-812

Wolffenbuttel BH, Boulanger CM, Crijns FR, Huijberts MS, Poitevin P, Swennen GN, Vasan S, Egan JJ, Ulrich P, Cerami A, Levy BI (1998) Breakers of advanced glycation end products restore large artery properties in experimental diabetes. Proc Natl Acad Sci USA 95:4630-4634

Wu L, Juurlink BH (2002) Increased methylglyoxal and oxidative stress in hypertensive rat vascular smooth muscle cells. Hypertension 39:809-814

Xie J, Reverdatto S, Frolov A, Hoffmann R, Burz DS, Shekhtman A (2008) Structural basis for pattern recognition by the receptor for advanced glycation end products (RAGE). J Biol Chem 283:27255-27269

Yan SF, Ramasamy R, Schmidt AM (2010) The RAGE axis: a fundamental mechanism signaling danger to the vulnerable vasculature. Circ Res 106:842-853

Yao D, Taguchi T, Matsumura T, Pestell R, Edelstein D, Giardino I, Suske G, Rabbani N, Thornalley PJ, Sarthy VP, Hammes HP, Brownlee M (2007) High glucose increases angiopoietin-2 transcription in microvascular endothelial cells through methylglyoxal modification of mSin3A. J Biol Chem 282(42): 31038-31045

Yoshida N, Okumura K, Aso Y (2005) High serum pentosidine concentrations are associated with increased arterial stiffness and thickness in patients with type 2 diabetes. Metabolism 54:345-350

Zhang Q, Tang N, Schepmoes AA, Phillips LS, Smith RD, Metz TO (2008) Proteomic profiling of nonenzymatically glycated proteins in human plasma and erythrocyte membranes. J Proteome Res 7:2025-2032

Zimmet P, Alberti KG, Shaw J (2001) Global and societal implications of the diabetes epidemic. Nature 414:782-787

Ziyadeh FN (2004) Mediators of diabetic renal disease: the case for tgf-Beta as the major mediator. J Am Soc Nephrol 15(Suppl 1):S55-S57 